\title{
Financial Intermediation and Stock Prices of Deposit Money Banks (DMBS) in Nigeria: a Panel Cointegration Approach
}

\author{
Yusuf Aina SOYEBO ${ }^{\star}$, Russell Olukayode C. SOMOYE ${ }^{\star \star}$
}

\begin{tabular}{l} 
A R T I C L E I N F O \\
\hline Article history: \\
Accepted March 2019 \\
Available online April 2019 \\
\hline JEL Classification \\
G12, G21 \\
Keywords: \\
Financial Intermediation, Financial \\
Acceleration, Stock Prices, Deposit \\
Money Banks, Nigeria
\end{tabular}

\begin{abstract}
A B S T R A C T
Considerable attention in finance literature had focused on the effect of financial intermediation on the economy and its determinants in different financial arrangements. This study examined the influence of financial intermediation on stock prices of Deposit Money Banks (DMBs) in Nigeria using data collected from all the quoted DMBs in the Nigeria between 2009 and 2016. The Panel Fully Modified Ordinary Least Square (FMOLS) regression techniques were adopted and the result shows that changes in variables such as deposits, loans, capital and management will result into an increase in the stock prices in the long run while a similar change in leverage, will result into a decrease in the stock prices. The study concluded that financial intermediation enhances the stock prices of DMBs in Nigeria. Therefore, it is recommended that investors should consider deposits, loans and capital base in their stock selection and portfolio construction involving DMBs' stocks in Nigeria.
\end{abstract}

(C) 2019 EAI. All rights reserved.

\section{Introduction}

In modern economic activities, the relevance of financial intermediation and intermediaries especially Deposit Money Banks (DMBs) cannot be overstated as they engaged in essential financial activities such as deposit mobilization, loan administration, risk diversification, delegated monitoring, corporate control and facilitating exchange among various economic agents (Levine, 1997). According to the bankbased approach to financial intermediation, the nature and magnitude of DMBs functions often determined the extent of financial development in the economy.

Similarly, Merton and Bodie (1995) observed the importance of financial intermediaries in the economy and opined that there relevance should be analysed based on services rendered to the financial system, (functional perspective) instead of existing institutions activities (institutional perspective). This is based on the assessment that over the years, financial intermediaries' functions through financial intermediation have been more stable than institutions. This has been a distinctive feature of the intermediary sector in the recent past as institutions emerged, matured and transformed overtime while their functional roles in the financial system remain constant, though design and delivered in substantially different ways (Somoye, 2011).

Furthermore, the relationship between financial intermediary (such as DMBs) health and business cycles is one of the rationale for government regulation, deposit insurance and capital requirements, while the possibilities of changes in public policies is a function of financial intermediaries positions. Thus, when banks reduced available credit to borrowers due to inadequate funding or poor deposit, credit crunch is a possible consequence in the economy even without a bank failure since the banking system serves as a monetary policy transmission mechanism for the regulatory authority (Peek \& Rosengren, 2000 and Karkowska, 2013). Inspite of these consequences, there are dearth of literature linking financial intermediaries' activities to their stock prices. This lead to a questions, can DMBs activities explain changes in their stock price in Nigeria?

Thus study examines the influence of DMBs financial intermediation such as deposit taking, capital, asset, loan and advances on their stock prices in order to establish the extent of variability in DMBs stock prices that are driven by their primary functions. The remaining segment of the paper comprise a brief literature review, materials and methods, results and discussion as well as conclusion and recommendations.

\footnotetext{
${ }^{\star}$ Lagos State University, Lagos; Nigeria, ${ }^{\star \star}$ Olabisi Onabanjo University, Ago-Iwoye, Nigeria. E-mail addresses: vusuf.soyebo@lasu.edu.ng, russell.somoye @oouagoiwoye.edu.ng.
} 


\section{Literature review}

Several studies have analyse financial intermediation due to its important role in facilitating liquidity and project finance through the channelization and transportation of financial resources among competing units in the economies. While most literature examined their influence on economic growth, fewer studies consider the financial intermediation influence on stock prices of DMBs. Ibrahim (2006) examined the dynamic interactions between bank loans and stock prices in order to explain the role played by bank loans in transmitting financial shocks in the economy using a six-variable VAR model and simulates generalized impulse response functions on quarterly data between 1978 and 1988.The variable of interest employed include bank loans, stock prices, real output, inflation rate, interest rate, and exchange rate in Malaysia. The study employed time-series techniques of cointegration, Vector Autoregression (VAR) and impulse response functions in examining the long run relationship and dynamic interactions among the variables of interest and the result revealed that bank loans is positively and significantly influenced by KLCI, GDP and INT but did not find a feedback effect from bank loans to stock prices.

Tennant \& Tracey (2014) examined the conditions under which banks in conducting their core functions impact stock market volatility in Jamaica using an unconditional descriptive measure of realized volatility and Generalized Autoregressive Conditional Heteroskedasticity (GARCH) specification on quarterly data such as deposit to total asset, loan to total asset, ratio of credit to private sector to total loans, spread, liquid asset ratio in a simple autoregression with exogenous variables (ARX). All the explanatory variables and their lags are put through a loop of pairwise granger causality tests to determine which variables (and at what specific lags) significantly improve the forecast of stock market volatility. The results showed that factors which affect banks' profitability can increase stock market volatility.

Similarly, Francis, Hasan, Song \& Yeung (2015) examined how bank regulation and supervision affect bank stock returns synchronicity using bank-specific fundamentals and stock price informativeness. It premised on the fact e that firm-specific stock return variations reflect both firm-specific variations in fundamentals resulting from firms pursuing idiosyncratic strategies and price recovery of firm value based on informed risk arbitrage. Using World Bank surveys on 35 countries, the study adopt two approaches; the first approach comprises direct controls such as activity restrictions, direct monitoring, disciplining from supervisory agents, and state ownership while the second approach comprises market empowering and protecting measures such as capital stringency and supervisory approaches that encourage private monitoring of banks. The result of the logistic OLS regression estimates showed that bank stock returns are less synchronous in countries with more stringent capital regulations, more supervision that emphasizes private monitoring, and less government bank ownership while Syed, Sumair \& Muhammad (2015) examined the most effective financial variable (debt-equity ratio, book to market value and firm size) in explaining stock prices using twenty six companies selected from pharmaceutical and chemical sector listed on the Karachi Stock Exchange between 2000 and 2009. The regression analysis result revealed that book to market value of equity is the most effective indicator.

Anwaar (2016) examined the influence of firm performance on stock returns in London Stock Exchange between 2005 and 2014 using explanatory variables such as earnings per share, quick ratio, return on assets, return on equity, and net profit margin against the stock returns in a panel regression specification. The analysis result showed that net profit margin, return on assets has got significant positive impact on stock returns while earnings per share has got significant negative impact on stock returns. Kühl (2017) examines the evolution of bank capital based on the share of non-state-contingent assets in banks' balance sheets and implications for macroeconomic dynamics using a new Keynesian dynamic general equilibrium model in order to gain an insight into how this composition affects shocks transmission in the economy. The results showed that shocks transmission to the real economy is caused by financial frictions in the banking sector is reduced as the size of non-state-contingent assets in banks' balance sheets increases. The study revealed that a mixture of assets in banks' balance sheets is key for shocks amplification in financial contract as non-state-contingent assets are signed before shocks are realized and their repayment is guaranteed and insulate banks' balance sheets from recent economic activity in the absence of defaults.

Blau, Brough \& Griffith (2017) examined opacity and its nature within firms as well as its influence on stock prices efficiency, focusing analysis on banks due to their opaqueness than other firms. They explore how bank prices incorporate market-wide information and reflects firm efficiency using firm-specific information, multivariate time-series analysis and vector auto regressive (VAR) process. The study captures stock prices inefficiency and find evidence supporting opacity which is positively related to price delay. This market-based measures of informational opacity and the asset composition of the bank's balance sheet which reduces the financial markets efficiency. The study suggests that the opacity of banks adversely influence the ability of outsiders to accurately value banks, which may lead to less informational efficiency in the stock prices of banks. 


\section{Materials and methods}

The study employed secondary data with a balanced panel which comprise quarterly data for financial intermediation from fifteen (15) quoted DMBs in Nigeria for the period of 2009-2016. The data were obtained from Nigerian Stock Exchange (NSE) and each DMBs Annual reports. This study examine the dynamic relationships between financial intermediation and stock prices using variables DMBs loans and advances, deposits, capital, asset and leverage. The mathematical equation for estimating the relationship between financial intermediation and stock prices of DMBs in Nigeria is derived from the financial accelerator general equilibrium model in line with Bernanke, Gertler \& Gilchrist (BGG) (1999), in which there are identical and competitive financial intermediaries (DMBs) that attract savings $\left(\mathrm{S}_{\mathrm{t}}\right)$ in form of deposit, with an initial capital $\left(\mathrm{C}_{\mathrm{t}}\right)$ in order to generate new fund $\left(\mathrm{C}_{\mathrm{t}+1}\right)$ part of which can be granted as loan and advances to investors based on the subsequent identical technology equation stated as :

$$
C_{t+1}=\Phi\left(\frac{S_{t}}{C_{t}}\right) C_{t}+(1-\delta) C_{t}
$$

where $\Phi(*)$ is an increasing and concave adjusted cost function that depends on the ratio of investment and capital while $\delta$ is the depreciation rate of capital. Once a loan is repaid, it is channeled to the DMBs. Thus, there are two important prices, the new capital $Q_{t}$ and previous capital $\bar{Q}_{t}$. Similarly, the DMBs attract used capital at a price $\bar{Q}_{t} S_{t,}$ invests $S_{t}$ and sells new capital for a revenue of $Q_{t} C_{t+1}$.

Hence, the economic problem facing a DMBs is how to maximize the excess or difference between the two prices given as:

$$
\begin{aligned}
& \max _{K_{t} I_{t}} Q_{t} C_{t+1}-S_{t}-\bar{Q}_{t} S_{t} \\
& \text { S.T. } C_{t+1}=\Phi\left(\frac{S_{t}}{c_{t}}\right) C_{t}+(1-\delta) S_{t}
\end{aligned}
$$

The optimality condition for in equation (3) is calibrated into two equilibrium prices as follows:

$$
\begin{aligned}
& Q_{t}=\left(\Phi^{\prime}\left(\frac{s_{t}}{c_{T}}\right)\right)^{-1} \\
& \bar{Q}_{t}=\left[(1-\delta)+\Phi\left(\frac{s_{t}}{c_{t}}\right)-\Phi^{\prime}\left(\frac{s_{t}}{c_{T}}\right) \frac{s_{t}}{c_{T}}\right] Q_{t}
\end{aligned}
$$

The BGG model is derived in equation (5) but the price of DMBs existing capital is different from that of the BGG and by introducing $\bar{Q}_{t}$ into the model, to serve as the BGG price on existing capital, the zero-profit condition is derived as:

which can also be restated as

$$
Q_{t} \Phi\left(\frac{S_{t}}{C_{t}}\right) C_{t}+Q_{t} C_{t}-S_{t}-Q_{t} S_{t}=0
$$

$$
\bar{Q}_{t}=Q_{t} \Phi\left(\frac{s_{t}}{c_{t}}\right)-\left(\frac{s_{t}}{c_{t}}\right)+Q_{t}
$$

Similarly, the strength of a DMBs to withstand operational shocks and market competition is a function of its capital $\left(C_{t}\right)$ and asset $\left(A_{t}\right)$. However, due to the nature of new fund (deposit), the DMBs are compelled by law to withhold certain fraction $\left(R_{t}\right)$ against unanticipated withdrawal. This reduced the size of available fund for lending and yield loan size $L_{t}=\left(C_{t}-R_{t}\right)$

Thus, attaining the maximization objective in equation (2) depends on other endogenous factors and by injecting them into the model, it will yield a normalized equation stated as:

Where

$$
P=\left(Q_{t} S_{t}, S_{t}, \bar{Q}_{t} C_{t}, L_{t}, A_{t}, C_{t}\right)
$$

$\mathrm{P} \quad=$ Profit

$Q_{t} S_{t}=$ Cost of used capital

$S_{t} \quad=$ Savings or Deposits

$\bar{Q}_{t} C_{t}=$ Revenue from the sales of new capital

$L_{t} \quad=$ Loans and advance

$A_{t}, \quad=$ Asset

Equally, DMBs activities usually affect the aggregate economic conditions due to their roles as a key financial intermediary and using $\pi_{t}$ to represents the difference between lending and deposit rate (spread). The equation (8) can be linearized as:

Where

$$
P=\left(S_{t}, L_{t}, A_{t}, C_{t}, \pi_{t}\right)
$$

$\mathrm{P} \quad=$ Stock prices 
$S_{t} \quad=$ Savings or Deposits

$L_{t} \quad=$ Loans and advance

$A_{t} \quad=$ Asset

$C_{t} \quad=$ Capital

$\pi_{t} \quad=$ Spread

Equation (9) form the base line equation for this study and other control variables that can influence stock prices are incorporated in line with evidence from literature.

\subsection{Estimation Procedure}

Panel Unit Root Test

A precondition in estimating a panel cointegration is the determination of stationarity (unit root) as well as long run cointegrating relationship in the data sets. This study employs the Im, Pesaran and Shin (IPS) panel unit root test, which is based on the well-known Augmented Dickey-Fuller (ADF) procedure and offered a panel unit roots test that combines time series information from cross sectional units, with fewer time observations required for the test to have power. The IPS test has superior competency above others in analysing long-run relationships in panel data and it specifies a separate ADF regression for each crosssection with individual effects and no time trend:



where $i=1, \ldots, N$ and $t=1, \ldots, T$

IPS adopts a different unit root tests for the $N$ cross-section units based on the ADF statistics averaged across groups. Thus, the average of the $t$-statistics for $\mathrm{p}_{1}$ from the individual ADF regressions, $\mathrm{t}_{\mathrm{iT}_{\mathrm{i}}}\left(\mathrm{p}_{\mathrm{i}}\right)$ : is stated as:

$$
\overline{\mathrm{t}}_{\mathrm{NT}}=\frac{1}{\mathrm{~N}} \sum_{\mathrm{i}=1}^{\mathrm{N}} \mathrm{t}_{\mathrm{iT}}\left(\mathrm{p}_{\mathrm{i}} \beta_{\mathrm{i}}\right)
$$

\section{Panel Cointegration Tests}

Having established the panel unit root test, a prerequisite condition for cointegration test is that all variables must be of order I(1). Once this condition is fulfilled, the next step is to test for the existence of a long-run cointegration the specified variables using panel cointegration tests suggested by Pedroni (2004) which comprise seven panel cointegration statistics in determining the fitness of the tests after normalizing the panel statistics with correction terms.

The estimated residual for the long-run regression is stated as:

$$
\mathrm{y}_{\mathrm{i}, \mathrm{t}}=\alpha_{\mathrm{i}}+\delta_{\mathrm{i}} \mathrm{t}+\beta_{1 \mathrm{i}} \mathrm{x}_{1 \mathrm{i}, \mathrm{t}}+\beta_{2 \mathrm{i}} \mathrm{x}_{2 \mathrm{i}, \mathrm{t}}+\ldots+\beta_{\mathrm{Mi}} \mathrm{x}_{\mathrm{Mi}, \mathrm{t}}+\mathrm{e}_{\mathrm{i}, \mathrm{t}}
$$

for $t=1, \ldots . ., T ; i=1, \ldots ., N ; m=1, \ldots ., M$,

where: $T$ is the number of observations over time, $N$ number of cross-sectional units in the panel, and $M$ number of regressors. In this set up, $\alpha_{i}$ is the member specific intercept which varies across individual crosssectional units. The same applies to the slope coefficients and member specific time intercepts, $\delta_{\mathrm{i}} \mathrm{t}$.

The heterogeneous panel and heterogeneous group mean panel cointegration test statistics are defines as into two sets as follows. Three main statistics $\mathrm{Z}_{\hat{\mathrm{v}}, \mathrm{N}, \mathrm{T}}, \mathrm{Z}_{\hat{\mathrm{\rho} N, T} 1}$ and $\mathrm{Z}_{\mathrm{tN}, \mathrm{T}}$ are based on pooled residuals within panel dimension and their statistics are as follows

$$
\begin{aligned}
& \mathrm{Z}_{\hat{\mathrm{v}}, \mathrm{N}, \mathrm{T}}=\mathrm{T}^{2} \mathrm{~N}^{3 / 2} \sum_{\mathrm{i}=1}^{\mathrm{N}} \sum_{\mathrm{t}=1}^{\mathrm{T}} \hat{\mathrm{L}}_{11 \mathrm{i}}^{2} \hat{\mathrm{e}}_{\mathrm{i}, \mathrm{t}}^{2} \\
& \mathrm{Z}_{\hat{\rho} \mathrm{N}, \mathrm{T} 1}=\mathrm{T} \sqrt{\mathrm{N}} \sum_{\mathrm{i}=1}^{\mathrm{N}} \sum_{\mathrm{t}=1}^{\mathrm{T}} \hat{\mathrm{L}}_{11 \mathrm{i}}^{2} \hat{\mathrm{e}}_{\mathrm{i}, \mathrm{t} 1}^{2} \sum_{\mathrm{i}=1}^{1} \sum_{\mathrm{t}=1}^{\mathrm{T}} \hat{\mathrm{L}}_{1 \mathrm{ii}}^{2}\left(\hat{\mathrm{e}}_{\mathrm{i}, \mathrm{t} 1} \Delta \hat{\mathrm{e}}_{\mathrm{i}, \mathrm{t}} \quad \hat{\lambda}_{\mathrm{i}}\right) \\
& \mathrm{Z}_{\mathrm{tN}, \mathrm{T}}=\tilde{\sigma}_{\mathrm{N}, \mathrm{T}}^{2} \sum_{\mathrm{I}=1 \mathrm{~T}=1}^{\mathrm{N}} \sum_{\mathrm{T}}^{\mathrm{T}} \hat{\mathrm{L}}_{11 \mathrm{i}}^{2} \hat{\mathrm{e}}_{\mathrm{i}, \mathrm{t} 1}^{2} \sum_{\mathrm{i}=1}^{1 / 2} \sum_{\mathrm{t}=1}^{\mathrm{N}} \hat{\mathrm{L}}_{11 \mathrm{i}}^{2} \hat{\mathrm{e}}_{\mathrm{i}, \mathrm{t} 1}^{2}\left(\hat{\mathrm{e}}_{\mathrm{i}, \mathrm{t} 1} \Delta \hat{\mathrm{e}}_{\mathrm{i}, \mathrm{t}} \hat{\lambda}_{\mathrm{i}}\right)
\end{aligned}
$$

where $\hat{\mathrm{e}}_{\mathrm{i}, \mathrm{t}}$ is the residual vector of the OLS estimation of Equation (12) and where the other terms are properly defined in Pedroni. 
The remaining statistics are based on pooled residuals between panel dimensions and allows for heterogeneous autocorrelation parameter across members. Their statistics are as follows:

$$
\begin{aligned}
& \tilde{Z}_{\hat{\rho} \mathrm{N}, \mathrm{T}}=\sum_{\mathrm{i}=1}^{\mathrm{N}} \sum_{\mathrm{t}=1}^{\mathrm{T}} \hat{\mathrm{e}}_{\mathrm{i}, \mathrm{t} 1}^{2} \sum_{\mathrm{t}=1}^{1}\left(\hat{\mathrm{e}}_{\mathrm{i}, \mathrm{t} 1} \Delta \hat{\mathrm{e}}_{\mathrm{i}, \mathrm{t}} \quad \hat{\lambda}_{\mathrm{i}}\right) \\
& \tilde{\mathrm{Z}}_{\mathrm{tN}, \mathrm{T}} 1=\sum_{\mathrm{i}=1}^{\mathrm{N}} \sum_{\mathrm{t}=1}^{\mathrm{T}} \hat{\mathrm{e}}_{\mathrm{i}, \mathrm{t} 1}^{2} \sum_{\mathrm{t}=1}^{1 / 2}\left(\begin{array}{lll}
\hat{\mathrm{e}}_{\mathrm{i}, \mathrm{t}}{ }_{1} \Delta \hat{\mathrm{e}}_{\mathrm{i}, \mathrm{t}} & \hat{\lambda}_{\mathrm{i}}
\end{array}\right)
\end{aligned}
$$

These statistics compute the group mean of the individual conventional time series statistics. The asymptotic distribution of each of these statistics are expressed as follows:

$$
\frac{\mathrm{X}_{\mathrm{N}, \mathrm{T}} \quad \mu \sqrt{\mathrm{N}}}{\sqrt{\mathrm{V}}} \Rightarrow \mathrm{N}(0,1)
$$

where $X_{N, T}$ is the corresponding from of the test statistics, while $\mu$ and $v$ are the mean and variance of each test respectively.

The result from the Pedroni Residual cointegration test will be compared with the Kao Residual Cointegration and Trace-Maximum Eigenvalue Cointegration Rank Test for result validity.

\subsection{Fully Modified Ordinary Least Squares (FMOLS) Estimation}

Once the outcome of the panel unit root and cointegration test satisfy the use of the FMOLS, the study employs the FMOLS procedure in order to obtain asymptotically efficient consistent estimates from the panel series which cater for non-exogeneity and serial correlation problems in regression analysis. It is well known that OLS estimation yields biased results because the regressors are endogenously determined in the $I(1)$ case. The starting point OLS as in the following cointegrated system for panel data:

$$
\mathrm{y}_{\mathrm{it}}=\alpha_{\mathrm{i}}+\mathrm{x}_{\mathrm{it}}^{\prime} \beta+\mathrm{e}_{\mathrm{it}}
$$

$$
\mathrm{x}_{\mathrm{it}}=\mathrm{x}_{\mathrm{i}, \mathrm{t} 1}+\varepsilon_{\mathrm{it}}
$$

where $\xi_{i t}=\left\lfloor\mathrm{e}_{\mathrm{it}}, \varepsilon_{\mathrm{it}}^{\prime}\right\rfloor$ is the stationary with covariance matrix $\Omega_{i}$. The estimator $\beta$ will be consistent when the error process $\omega_{\mathrm{it}}+\left[\mathrm{e}_{\mathrm{it}}, \varepsilon_{\mathrm{it}}^{\prime}\right]^{\prime}$ satisfies the assumption of cointegration between $y_{i t}$ and $x_{i t}$. The limiting distribution of OLS estimator depends upon nuisance parameters. Based on the position of Phillips and Hansen (1990), a semi-parametric correction is required the OLS estimator to eliminates the second order bias arising from endogenous regressors. Pedroni (2000) adopts the same principle and allows for the heterogeneity in the short run dynamics and the fixed effects. FMOLS Pedroni's estimator is constructed as follow:

$$
\begin{aligned}
\hat{\beta}_{\mathrm{FM}} \quad \beta=\sum_{\mathrm{i}=1}^{\mathrm{N}} \hat{\Omega}_{22 \mathrm{i}}^{2} \sum_{\mathrm{t}=1}^{\mathrm{T}}\left(\mathrm{x}_{\mathrm{it}} \quad \hat{\mathrm{x}}_{\mathrm{t}}\right)^{2} \sum_{\mathrm{i}=1}^{1} \hat{\Omega}_{11 \mathrm{i}}^{1} \hat{\Omega}_{22 \mathrm{i}}^{1} \sum_{\mathrm{t}=1}^{\mathrm{T}}\left(\mathrm{x}_{\mathrm{it}} \overline{\mathrm{x}}_{\mathrm{t}}\right) \mathrm{e}_{\mathrm{it}} \mathrm{T} \hat{\gamma}_{\mathrm{i}} \\
\hat{\mathrm{e}}_{\mathrm{it}}=\mathrm{e}_{\mathrm{it}} \quad \hat{\Omega}_{22 \mathrm{i}}^{1} \hat{\Omega}_{21 \mathrm{i}}, \quad \hat{\gamma}_{\mathrm{i}}=\hat{\Gamma}_{21 \mathrm{i}}+\hat{\Omega}_{21 \mathrm{i}}^{0} \quad \hat{\Omega}_{22 \mathrm{i}}^{1} \hat{\Omega}_{21 \mathrm{i}}\left(\hat{\Gamma}_{22 \mathrm{i}}+\hat{\Omega}_{22 \mathrm{i}}^{0}\right)
\end{aligned}
$$

where the covariance matrix can be decomposed as $\Omega_{\mathrm{i}}=\Omega_{\mathrm{i}}^{0}+\Gamma_{\mathrm{i}}+\Gamma_{\mathrm{i}}$

$\Omega_{\mathrm{i}}^{0}$ is the contemporaneous covariance matrix,

$\Gamma_{i}$ is a weighted sum of autocovariances.

$\hat{\Omega}_{\mathrm{i}}^{0}$ denotes an appropriate estimator of $\Omega_{\mathrm{i}}^{0}$.

Thus, this study employs panel group FMOLS test from Pedroni (2000). The test statistics constructed from the panel group estimators are designed to test the null hypothesis $\mathrm{H}_{0}: \beta_{\mathrm{i}}=\beta_{0}$ for all $i$ against the alternative hypothesis $\mathrm{H}_{\mathrm{A}}: \beta_{\mathrm{i}} \neq \beta_{0}$, such that the values for $\beta_{\mathrm{i}}$ are not constrained as the same with the alternative hypothesis. 


\subsection{Results and discussions}

Table 1: Im, Pesaran and Shin W-stat Panel Unit Root Test Results for the variables

\begin{tabular}{|l|c|c|c|c|}
\hline & \multicolumn{2}{|c|}{ Level } & \multicolumn{2}{c|}{ First Difference } \\
\hline & Statistic & Prob. & Statistic & Prob. \\
\hline Stock price & -0.2831 & 0.3886 & -11.8404 & $0.0000^{* *}$ \\
\hline Deposits & 2.3896 & 0.9916 & -6.3096 & $0.0000^{* *}$ \\
\hline Loans & 10.5663 & 1.0000 & -11.1423 & $0.0000^{* *}$ \\
\hline Capital & 12.6007 & 1.0000 & -4.3368 & $0.0000^{* *}$ \\
\hline Asset & 4.1573 & 1.0000 & -6.9581 & $0.0000^{* *}$ \\
\hline Leverage & 3.5825 & 0.9998 & -8.3553 & $0.0000^{* *}$ \\
\hline Management & -2.9598 & 0.1050 & -8.8373 & $0.0000^{* *}$ \\
\hline \multicolumn{5}{|c|}{ Source: Author's Computation Using E-views 8 } \\
$* *$ Significant at 5\% level of significance
\end{tabular}

Table 1 presents the results of Im-Pesaran-Shin (IPS) Panel Unit Root Test Results for level and first differences of all the quarterly time series data. The IPS test allows for heterogeneous coefficients with the null hypothesis that all series follow a unit root process and to reject this, the IPC probability value must be less than or equal the level of significance value of 0.05. The IPS test revealed that all variables are not stationary at level but tend stationary at first difference.

Table 2: Pedroni Residual Cointegration Test Result

\begin{tabular}{|c|c|c|c|c|}
\hline $\begin{array}{c}\text { Common Auto-Regressive coefficients } \\
\text { (within-dimension) }\end{array}$ & $\underline{\text { Statistic }}$ & Prob. & $\begin{array}{c}\text { Weighted } \\
\text { Statistic }\end{array}$ & Prob. \\
\hline Panel v-Statistic & -0.2029 & 0.5804 & -0.3976 & 0.6545 \\
\hline Panel rho-Statistic & 1.4007 & 0.9193 & 1.4454 & 0.9258 \\
\hline Panel PP-Statistic & -1.2616 & 0.0135 & -1.6980 & 0.0448 \\
\hline Panel ADF-Statistic & -1.5394 & 0.0019 & -2.2241 & 0.0131 \\
\hline \multicolumn{5}{|l|}{} \\
\hline Individual Auto-Regressive coefficients (between-dimension) \\
\hline \multicolumn{6}{|c|}{ Statistic } & Prob. & \\
\hline Group rho-Statistic & 2.6548 & 0.9960 & & \\
\hline Group PP-Statistic & -2.2505 & 0.0122 & \\
\hline Group ADF-Statistic & -2.6806 & 0.0037 & \\
\hline Source: Author's Computation Using E-views 8 \\
\end{tabular}

Table 2 reveals the result of the Pedroni residual cointegration test which shows that two (Panel PP and ADF statistics) out of the four statistics under common auto-regressive coefficients (within-dimension) rejected the null hypothesis of no cointegration in the data series, while two (Group PP and ADF statistics) out of the three under the individual auto-regressive coefficients (between-dimension) rejected the hypothesis of no cointegration in the data series. The Pedroni result was confirmed by Kao Residual, Trace and Maximum Eigenvalue Cointegration Test and their results as presented in table 2 and 3 below were in accordance with the Pedroni residual cointegration result.

Table 3 Kao Residual Cointegration Test Result

\begin{tabular}{|c|c|c|}
\hline & t-Statistic & Prob. \\
\hline ADF & -2.5441 & 0.0055 \\
\hline Residual variance & 0.0140 & \\
\hline HAC variance & 0.0108 & \\
\hline \multicolumn{2}{|c|}{ Source: Author's Computation Using E-views 8 }
\end{tabular}

The Kao Residual cointegration test result in table 3 reveals a probability value of 0.0055 which is less than 5\%. This implies that the null hypothesis of the Kao test which state that there is no cointegration in the specified variables is rejected. This was proven by the Trace and Maximum Eigenvalue cointegration rank test result presented in table 4 below:

Table 4: Trace and Maximum Eigenvalue Cointegration Rank Test Result

\begin{tabular}{|c|c|c|c|c|}
\hline $\begin{array}{c}\text { Hypothesized } \\
\text { No. of CE(s) }\end{array}$ & $\begin{array}{c}\text { Trace test } \\
\text { Statistics }\end{array}$ & Prob. & $\begin{array}{c}\text { Max-Eigen } \\
\text { Statistics }\end{array}$ & Prob. \\
\hline None & 459.1 & 0.0000 & 316.3 & 0.0000 \\
\hline At most 1 & 229.8 & 0.0000 & 112.9 & 0.0000 \\
\hline At most 2 & 152.5 & 0.0000 & 83.49 & 0.0000 \\
\hline
\end{tabular}




\begin{tabular}{|c|c|c|c|c|}
\hline $\begin{array}{c}\text { Hypothesized } \\
\text { No. of CE(s) }\end{array}$ & $\begin{array}{c}\text { Trace test } \\
\text { Statistics }\end{array}$ & Prob. & $\begin{array}{c}\text { Max-Eigen } \\
\text { Statistics }\end{array}$ & Prob. \\
\hline At most 3 & 122.7 & 0.0000 & 82.80 & 0.0000 \\
\hline At most 4 & 64.40 & 0.0003 & 56.32 & 0.0025 \\
\hline At most 5 & 35.57 & 0.2226 & 26.50 & 0.6494 \\
\hline At most 6 & 48.46 & 0.0178 & 48.46 & 0.0178 \\
\hline
\end{tabular}

The table 4 shows that the Trace test and Maximum Eigenvalue statistics values of 64.40 and 56.32 are significant at 5\% level of significance respectively. This implies that the null hypothesis of no long run cointegrating relationship is rejected. Instead there are four possible cointegrating equation among the variables Thus, DMBs stock prices, deposits, loans, capital, asset, leverage and management cointegrated for dynamic panel analysis as they move together in the long run. Having fulfilled the necessary conditions for running the panel FMOLS as shown in the preceding analysis, the result of the FMOLS analysis is presented in the table below:

Table 5: Panel Fully Modified Least Squares (FMOLS) Result

\begin{tabular}{|c|c|c|c|c|}
\hline Dependent Variable: STOCK_PRICE \\
\hline Variable & Coefficient & Std. Error & t-Statistic & Prob. \\
\hline DEPOSITS & 0.2751 & 0.0671 & 4.1023 & $0.0000^{*}$ \\
\hline LOANS & 0.3490 & 0.0749 & 4.6598 & $0.0000^{*}$ \\
\hline CAPITAL & 0.1911 & 0.0381 & 5.0104 & $0.0000^{*}$ \\
\hline ASSET & 0.0140 & 0.0429 & 0.3264 & 0.7443 \\
\hline LEVERAGE & -0.2619 & 0.0328 & -7.9854 & $0.0000^{*}$ \\
\hline MGT & 0.4396 & 0.1699 & 2.5882 & $0.0100^{*}$ \\
\hline R-squared & 0.8529 & Mean dependent var & 0.6893 \\
\hline Adjusted R-squared & 0.8460 & S.D. dependent var & 0.4720 \\
\hline S.E. of regression & 0.1852 & Sum squared resid & 14.7877 \\
\hline Durbin-Watson stat & 0.5142 & \multicolumn{2}{|l}{ Long-run variance } & 0.0168 \\
\hline \multicolumn{7}{|l|}{ Source: Author's Computation Using E-views 8 } \\
\end{tabular}

*Significant at $5 \%$ level of significance

Table 5 shows the Panel Fully Modified Least Squares result coefficients, standard error, t-statistics and probability values for all the selected variables. The result coefficients shows the influence of specified independent variables such as deposits, loans, capital, asset, leverage and management on stock prices of DMBs in Nigeria and it is observed that a unit change in variables such as deposits $(0.2751, \mathrm{p}<0.05)$, loans (0.3490, p < 0.05), capital (0.1911, p < 0.05), asset $(0.0140, \mathrm{p}<0.05)$, and management $(0.4396, \mathrm{p}<0.05)$, will result into an increase in the stock prices in the long run while a similar change in leverage $(-0.2619, \mathrm{p}>$ 0.05), will result into a decrease in the stock prices in the long run. This implies that majority of the independent variables specified in this model contribute positively towards the stock prices and are significant at $5 \%$ level of significance.

Similarly, the coefficient of determination (R-square) value of 0.8529 indicates that $85.29 \%$ of variations in stock prices are attributable to changes in variables such as deposits, loans, capital, asset, leverage and management at the firm level while standard error of the regression value of 0.1852 supports the overall fitness of the model in explaining the stock prices.

\section{Conclusions}

The result indicates that variables such as DMBs variables such as deposits, loans, capital, leverage, asset and management are affect stock prices and it implies that financial intermediation have a long run influence on stock prices of DMBs in Nigeria. This study revealed that DMBs deposits, loans, capital directly influence stock prices as their changes positively influence stock price. This implies that a stable increase in DMBs deposit, loans and capital has the prospect of increasing the share price in Nigeria as it increase investors' confidence of the firm ability to absorb operational loss and spur demand for the firm stock which tends to increase the stock prices. The DMBs capital is a key tool for unsystematic risk absorption, loan agreement sustenance and receiving adequate information about borrowers' businesses. Winton (1995) opined that bank capital/ shareholders' fund is a mechanism for loss absorption and probability of bank defaults. Thus, bank capital is an important mechanism for implementing delegated monitoring.

In the same vein, this study established that bank asset exact a direct influence on stock price with the implication that as a bank asset size increase, its will compel an increasing trend in its stock prices. This submission is in line with the views of Hoechle, Schmid, Walter \& Yermack (2012), Blau, Brough \& Griffith (2017) and Kühl (2017) as increase in firm asset and capital often compels changes in its shares to several 
factors such as managerial self-interest which makes it possible to channel internal cash flows to the most profitable investment outlet. Similarly, increased asset size aids diversification across sectors which improve monitoring incentives, reduces returns dispersion and shrink risk shifting benefits.

There is a need for economic managers and policymakers to realize the nature of the DMBs activities in Nigeria and should consider the required lag in any programme, design to control DMBs in terms stock prices, as most of the financial intermediation measures adopted in this study showed a statistically significant longrun influence while only loans disbursement functions had a significant short-term effects. Similarly, there is a need for DMBs managers to understand the influence of their activities on stock prices and use it as a gauge to measure investors' confidence and preference. This is essential in order to monitor investors' attitude towards their firm and put in place strategies and tactics that will continuously strengthen their market price based on their current performance and future possibilities.

\section{References}

1. Anwaar, M. (2016), "Impact of Firms Performance on Stock Returns, Evidence from Listed Companies of FTSE-100 Index London, UK", Global Journal of Management and Business Research.

2. Bernanke, B. S., Gertler, M. \& S. Gilchrist (1999), "The financial accelerator in a quantitative business cycle framework" in Handbook of Macroeconomics, ed. by J. B. Taylor and M. Woodford, Elsevier, 1(15), pp. 1341-1393.

3. Blau, B. M., Brough, T. J., \& Griffith, T. G. (2017), "Bank opacity and the efficiency of stock prices" Journal of Banking \& Finance, 76, pp. 32-47.

4. Francis, B. B., Hasan, I., Song, L., \& Yeung, B. (2015), "What determines bank-specific variations in bank stock returns? Global evidence" Journal of Financial Intermediation, 24(3), pp. 312-324.

5. Hoechle, D., Schmid, M., Walter, I., \& Yermack, D. (2012), "How much of the diversification discount can be explained by poor corporate governance" Journal of Financial Economics, 103(1), pp. 41-60.

6. Ibrahim, M. H. (2006), "Stock prices and bank loan dynamics in a developing country: The case of Malaysia" Journal of Applied Economics, 9(1), pp. 71.

7. Karkowska, R. (2013), "The empirical analysis of dynamic relationship between financial intermediary connections and market return volatility" Browser download paper.

8. Kühl, M. (2017), "Bank capital, the state contingency of banks' assets and its role for the transmission of shocks" Journal of Macroeconomics, 54, pp. 260-284.

9. Levine, R. (1997), "Finance and growth: theory and evidence" Handbook of economic growth, 1, pp. 865-934.

10. Merton, R. C., \& Bodie, Z. (1995), "A conceptual framework for analyzing the financial system. The global financial system" A functional perspective, pp. 3-31.

11. Pedroni, P. (2000), "Fully Modified OLS for Heterogenous Cointegrated Panels and the Case of Purchasing Power Parity". Working paper, North American Econometric Society Summer Meeting, pp. 96-120.

12. Pedroni, P. (2004), "Panel Cointegration: Asymptotic and finite samples properties of pooled time series Tests with an application to the PPP hypothesis" Economic Theory 20: pp. 597-625

13. Peek, J., \& Rosengren, E. S. (2000), "Collateral damage: Effects of the Japanese bank crisis on real activity in the United States". American Economic Review, pp. 30-45.

14. Phillips, P. C., \& Hansen, B. E. (1990), "Statistical inference in instrumental variables regression with I(1) processes, The Review of Economic Studies, 57(1), pp. 99-125.

15. Somoye, R.O.C. (2011), "Role of Financial Intermediation in Entrepreneurship Financing in Nigeria" Unpublished Ph.D Thesis, University of the West of Scotland, Scotland United Kingdom.

16. Syed, Sumair \& Muhammad (2015), "Stock Returns Indicators: Debt to Equity, Book to Market, Firm Size and Sales to Price" Journal of Poverty, Investment and Development. 16: pp. 25-33

17. Tenant D.F. \& Tracey M.R. (2014), "Financial intermediation and stock market volatility in a small bank-dominated economy", The Journal of Developing Areas, 48(4) pp. 73-95.

18. Winton, A. (1995), "Delegated monitoring and bank structure in a finite economy". Journal of Financial Intermediation, 4(2), 158-187. 